論 文

\title{
水辺管理区域の現況と炎の保全が林業に及ぼす影響 岩手山周辺地域を事例として——
}

\author{
久保山裕史 ${ }^{*, 1}$, 西 園朋 広 $^{2}$, 大石 康 彦 ${ }^{2}$, 粟 屋 善 雄 ${ }^{1}$, 古井戸宏通 ${ }^{2}$ \\ 天野智将 ${ }^{2}$, 田中邦宏 ${ }^{3}$, 横田康 裕 $^{4}$
}

\begin{abstract}
久保山裕史 - 西園朋広 - 大石康彦・粟屋善雄・古井戸宏通・天野智将・田中邦宏・横田康裕：水辺管理区域の現況と炎の 保全が林業に及ぼす影響一岩手山周辺地域を事例として一 日林誌 $87: 410 \sim 418,2005$ 数值地図, 現存植生図, 森林資 源 GIS デー夕等を用いて岩手山周辺地域の植生状況と水辺管理区域（RMZ）の施業規制が木材生産に及ぼす影響を分析し

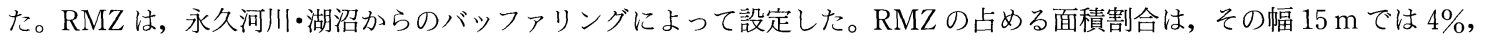
$50 \mathrm{~m}$ では 11\%に達した。森林区域以外の RMZでは, 森林はわずかであることから, 水辺林回復が必要である。一方, 森林 区域の RMZ では，人工林率は少ないが，民有林では高龄林が少なく，保全の必要がある。また，RMZを含む林分は，出材 しやすい場所が多く，民有林の林分は高い割合で RMZ に包含された。現状の規制は緩く，RMZ を禁伐とした場合の補償額 は, 幅を広くとるほど高額となる。他方, 小面積林分を規制対象から除外すると, 保全されるべき RMZが断片化した。以上 から，個人有林等に対しては RMZ の幅を小さくし，施業要件を緩和する等の措置が適当と考えられる。 キーワード：岩手山周辺地域，GIS，水辺管理区域，施業規制，林業
\end{abstract}

Kuboyama, H., Nishizono, T., Ohishi, Y., Awaya, Y., Furuido, H., Amano, T., Tanaka, K., and Yokota, Y.: Status of Riparian Management Zone and Impacts of Its Preservation on Forestry : Case Study of Mt. Iwate and the Surrounding Area, Iwate Prefecture. J. Jpn. For. Soc. $87: 410 \sim 418,2005$ On Mt. Iwate and the surrounding area, vegetation of the riparian management zone and impacts of its harvest restriction on forestry were examined by using Digital Topographical Map 25000, Digital Vegetation Map, and digital forest resources data. The riparian management zone (RMZ) was set up with buffering from permanent channels and lakes. RMZ shared $4 \%$ and $11 \%$ under buffer width of $15 \mathrm{~m}$ and $50 \mathrm{~m}$ respectively. In RMZ outside forest planning area, the riparian forest should be restored because a few forests currently existed there. In the RMZ inside forest planning area, the ratio of plantation forest was lower than in the whole area. However, non-national forests in RMZ needed to be preserved since in many forest stands their age was not high enough. Forest stands including RMZ were generally located near road and many of them had a high ratio of RMZ area to whole stand area. Present restriction to those stands is very inattentive. If the harvest in RMZ is prohibited, compensation for the restriction would become a higher value as the buffer width would be wider. On the other hand, RMZ was fragmented in cases where small stands would be exempted. Therefore, to introduce RMZ harvest restriction efficiently, a narrower RMZ width and moderate restriction would be appropriate for non-national forests.

Key words : forestry, GIS, harvest restriction, Mt. Iwate and the surrounding area, riparian management zone

\section{I. 背景と目的}

水辺域は，渓畔林研究会（1997）によれば，水域生態系 および水域環境と直接影響しあう, 渓流・河川・湖沼およ び隣接する側方流路 (間欠河川), 氾濫原, 湿地带を含んで いる。つまり，陸域と水域の生態系を互いに結びつけるイ ンターフェースの役割をしている。

生態系における水辺域の役割に関する研究は, 欧米にお ける 1990 年前後の野生生物保護運動を一つの契機として 発展し, 我が国においても精力的に進められている（鷲
谷・草刚編，2003）。そして，水辺域は生態系にとって， (1)日光の遮断 (水温維持), (2)落葉・落下昆虫の供給, (3)倒 木の供給，(4)河岸浸食防止，(5)水質保全（硝酸塩・微細砂 等の流出防止), (6)水生生物の保護, (7)野生動物の生息地回廊機能, 8微気象の保全等の重要な機能を果たしている ことが明らかとなり，世界的にその保全に向けた取り組み が開始されている（高橋ら，2003）。

これまで自然に近い状態で残されている水辺林は減少を 続けてきた（岡村・孫田，2000）。そうした中で，我が国に おいても, 水辺域の保全・修復に向けた制度が構築されつ

* 連絡・別刷請求先 (Corresponding author) E-mail : kuboyama@ ffpri.affrc.go.jp

1 (独) 森林総合研究所 (305-8687 つくば市松の里 1)

Forestry and Forest Products Research Institute, 1 Matsunosato, Tsukuba 305-8687, Japan.

2 (独) 森林総合研究所東北支所 (020-0123 盛岡市下厨川字鍋屋敷 92-25)

Forestry and Forest Products Research Institute Tohoku Research Center, 92-25 Nabeyashiki, Shimo-Kuriyagawa, Morioka 020-0123, Japan.

3 (独) 森林総合研究所関西支所（612-0855 京都市伏見区桃山町永井久太郎 68）

Forestry and Forest Products Research Institute Kansai Research Center, 68 Nagaikyutaro, Momoyama, Kyoto 612-0855, Japan.

4 (独) 国際農林水産業研究センター (305-8686 つくば市大わし 1-1)

Japan International Research Center for Agricultural Sciences, 1-1 Ohwashi, Tsukuba 305-8686, Japan.

(2004 年 10 月 8 日受付；2005 年 6 月 16 日受理) 
つある。柿澤（2000）によれば，1997 年の河川法改正に よって，河川管理の目的に「水質や生態系など河川環境の 整備と保全」が明記され,「周辺の一定幅の樹林帯を, 保安 林制度等と調整の上，河川管理施設として整備または保全 することができる」ようになった。しかし，河川や護岸， 堤防内部といった河川区域は国土交通大臣や自治体の長が 管理者となっているので比較的容易に保全できるが，河川 区域以外の土地の管理（規制）を行う場合，さまざまな所 有形態と土地利用が存在するため, 土地所有権の問題や土 地利用に関わる主務官庁との調整やその規制法の問題か ら，河川法のみでは対処できない。

柿澤（2000）はさらに，土地関連法規の殆どは水辺域保 全を全く想定していないことを指摘している。確かに，森 林法をはじめとする森林関連法規において, 水辺林に言及 しているものは見あたらない。このことは，より実効性を 持って水辺林を保全するためには，新たな法制度の制定あ るいは既存法制度の改正が必要であることを意味してい る。同時に，そうした法制度の立案にあたっては，市民や 業界団体，関連省庁等と，さらに，それを実施しょうとし た場合, 土地所有者との合意形成が不可欠であることを意 味している。

民有林における水辺林の保全に関しては, 米国のワシン トン州における，水辺域の保全に向けた先進的な取り組み が参考になる。同州では, 1992年に森林施業規則 (Washington Forest Practice Board, 2001） が改正され，水辺管理 区域（Riparian Management Zone, 以下 RMZ) が設定さ れた。この時点では, 住民の生活や生物に関る永久河川の 両岸を対象に, 州の西側では平水時の水際から川幅に応じ て 7.5〜30 m の範囲に RMZ は設定された。そこでは, $50 \%$ 以の立木を残置することとなったが，許可を受けれ ば林業機械の使用や集材路作設は可能であった。その後, 2001 年に改正が行われ, RMZ は, 核心区域 (core zone), 中間区域 (inner zone), 外縁区域 (outer zone) の三つに 拡充され, 最大 $60 \mathrm{~m}$ となった。そして, 州の西側では, 該 当河川の水際から $15 \mathrm{~m}$ の範囲は核心区域となり, 森林の 伐採は禁止され，環境に配慮して設計・許可された林道以 外は作設不可となるなど，施業規制が大幅に強化された。 また, 核心区域から最大 $30 \mathrm{~m}$ 幅の中間区域内では, 立木 の伐採を行うことができるが，地位 III の林分の場合， 140 年生時の胸高断面積合計が $58 \mathrm{~m}^{2} / \mathrm{ha}$ 以上になるような択 伐が求められている。その外側の最大 $20 \mathrm{~m}$ 幅の外縁区域 では, 胸高直径 $30 \mathrm{~cm}$ 以上の残存木を 50 本/ha 以上保残 しなければならないことになっている。

こうした法制度の変更は，林業・林産業界に大きな影響 を与えている。たとえば，大手林業会社であるプラムク リーク社における久保山（2001）の聞き取り調査から, 林 業における近年最も大きなりスクは環境規制の強化であ り，上述の規制によって同社が州内に所有する森林面積の 約 $20 \%$ が影響を受けていることが明らかとなった。ただ し, 個人有林への影響を緩和するために, 同法律では, 8 ha
以下の林分や，所有面積合計が 32 ha 以下の所有者につい ては，規制の適用除外としている。

一方, 日本国内に扔いても，2002 年に自然再生推進法が 制定されるなど，水辺域の保全に向けた対策が求められつ つある。そうした対策の一つの指針として, 青森, 岩手, 秋田の三県は, 北東北の森林生態系の健全性や活力を保ち ながら，森林を管理・経営するための「北東北の持続可能 な森林経営に向けた基準と指標」を策定した（緑のグラン ドデザイン検討委員会・基準と指標を検討する専門部会, 2001)。この「基準と指標」においては,「渓流の両岸合計 で $100 \mathrm{~m}$, 尾根の両側合計で $100 \mathrm{~m}$ の範囲は広葉樹林を保 全 (到達目標) し，すでに人工林化された森林においては, 自然侵入する広葉樹を育成して針広混交林, 広葉樹林へと 誘導するもの」とし, RMZ と同様に, 緩衝帯として川岸か ら $50 \mathrm{~m}$ の幅が想定されている。今のところ,「基準と指 標」は具体的な政策に反映されていないため, 影響は出て いないが，ワシントン州の施業規則を実施すると，日本で は小班 (所有森林の一つのまとまり) 規模が小さいために, 禁伐となる核心区域に小班の大部分が含まれてしまう等の 影響が出ることが予想される。

そこで本論では，まず，水辺域がその多様な機能を果た しうる状況にあるのかについて検討するために，地理情報 システム (以下, GIS) を用いて, 研究対象地域の植生の概 況を明らかにし，RMZ に該当する土地の植生分布に基づ いて, 森林計画対象区域に扔ける水辺林分の位置づけを 行った。その上で，森林計画対象区域の資源状況を明らか にし，RMZ を導入した場合の森林所有者への影響につい て検討した。

\section{II. 資料と分析方法}

\section{1. 分析対象}

分析対象地としては, 岩手県の 5 市町村（盛岡, 零石, 西根, 滝沢, 松尾）からなる地域から, 水系に基づいて北 上川以西，零石川以北を抜き出し，さらに，デー夕の制約 から国道 282 号線の東側を除いた岩手山周辺地域（以下， 地域)とした (図-1)。この地域は，イワナやヤマメ等の渓 流魚が豊富である（東北の渓流釣り場ガイド編集部, 1998)。また, 対象地域の秋田県境部には暮根田川上流部の 森林生態系保護地域が位置し, それを南北に貫いて国有林 の緑の回廊が設定されている。そこは, イヌワシやクマタ 力等の希少種（環境省, 2004）や特別天然記念物に指定さ れているカモシカ, ツキノワグマ等の多様な野生鳥獣の生 息域となっている(藤森ら，1999）。以上のことから，この 地域は水辺域保全の意義があると考える。なお, 同地域は, 県庁所在地の市街地を内包していると同時に, 素材生産量 が 3 万 $\mathrm{m}^{3}$ を越している (岩手県農林水産部, 2002)ことか ら, 調和のとれた森林利用を考える必要が高いことも特徵 といえる。

\section{2. 森林資源および水辺域等のデータ}

地図デー夕は, すべて平面直角座標系第 $\mathrm{X}$ 系に変換し, 
面積や長さについては GIS ソフトArcView（米国 ESRI 社）上での解析結果を使用した。

1）森林資源デー夕

国有林の地図データについては, 対象地域に関わる 2000 年時点の森林基本図（縮尺 5 千分の一）を東北森林管理局 から入手し, デジタイズした後に地理座標を与えた。同様 に, 森林資源デー夕については, 森林調査簿と樹種簿を入 手した。民有林部分については，岩手県の保有する森林資 源 GIS デー夕（森林基本図等の地図データおよび森林簿 データ）の 2001 年時点のものを利用した。

地図デー夕における国有林と民有林の境界部分では，わ ずかに重複，あるいは非接合の状態になっているが，それ らはランダムであることから相殺されることと, 解析上無 視できる程度であることから，修正せずにそのまま解析を 行った。森林資源データで用いた項目は, 国有林について は, 林班, 小班, 保護林, レクの森, 保安林, 法令等, 施 業群，樹種，混交步合，林齢，総蓄積である。民有林につ いては, 林班, 小班, 施業番号, 施業枝番, 森林所有形態, 保安林, 公園, 制限林, 伐採方法, 樹種, 混交歩合, 林齢, 立木・材積を用い，国有林とはコード体系が異なるので， 集計は別々に行った。

以上の二つをあわせたものを森林区域と呼ぶ。地図上の 林分（ポリゴン）は, 国有林では小班を単位とし，民有林 では林齢や樹種によって小班がさらに施業番号で区分され ていることから，これを単位とした。なお，国有林・民有 林ともに，同一の林分に対して，林齢や樹種が異なる（混 交している）場合には, 複数のレコードが保存されている。

2）水辺域のデー夕と設定

水辺域を地図上で特定するために, 国土地理院「数值地 図 25000 空間デー夕基盤」の，河川中心線を用いた。国土 地理院（2003）によれば，河川中心線は平水時幅 $1.5 \mathrm{~m}$ 以 上，長さ $250 \mathrm{~m}$ 以上の永久河川を対象としていることか ら, 魚類が生息している可能性が高い。また, 東北 3 県の 「基準と指標」が国土地理院の 2 万 5 千分の一の地形図に おける水系を渓流の目安としていることも河川中心線を用 いた理由の一つである。なお， ワシントン州の森林施業規 則では川幅 $0.6 \mathrm{~m}$ 以上を対象としていることから, ほぼ整 合している。

河川は平水時の川幅が $5 \mathrm{~m}$ 未満の一条河川と, $5 \mathrm{~m}$ 以上 の二条河川に分類されており，後者については平水時の水 ぎわの境として水涯線が記述されている。そこで，川幅の 空間情報がない一条河川については河川中心線からの距離 に基づき，二条河川については川岸の空間情報である水涯 線からの距離に基づいて RMZ を設定した（中州は，河川 水面に含めた)。

ところで, 水涯線には, $25 \mathrm{~m} \times 25 \mathrm{~m}$ 以上の湖沼の外縁も 含まれている。そこには，人工湖も含まれているが，それ らも水生生物の生息地の一つとなっていることから水辺域 の対象とした。河川についても, 同様に農業用水路等の人 工物が含まれている。
3）その他のデータ

道路についても「数値地図 25000 空間デー夕基盤」の道 路区間デー夕を用いた。そして，林道を含む幅 $1.5 \mathrm{~m}$ 以上 の軽車道より大きなものを解析対象とし，トンネルや橋梁

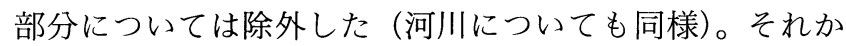
ら，地形と森林分布との関係を検討するために，日本地図 センターの数值地図 $50 \mathrm{~m}$ メッシュ（標高）を用いた。

なお，対象地域における森林以外の植生（土地利用）に ついて把握するために，環境省が自然環境保全基礎調査の 結果に基づいて作成した，「自然環境情報 GIS」の現存植 生図データ（5 万分の一）を用いた（第 3 回調査に基づく現 存植生図に第 4 回および第 5 回調査の現存植生改変図を重 ねた)。

\section{3. 解析方法}

1） $\mathrm{RMZ}$ の設定

本論では，保全すべき水辺域とその緩衝帯を含む区域 を, 米国の例にならって, RMZ と呼ぶ。 RMZ は, 本来, 川岸からの距離によって設定されるが，一条河川について はデータの制約から, 河川中心線から一定距離のバッ ファーを河川の両側に対して発生させることによって作成 した（その平水時の川幅は $1.5 \sim 5 \mathrm{~m}$ 末満であるので, RMZ の幅は $0.75 \sim 2.5 \mathrm{~m}$ 過少となる)。二条河川や湖沼等 の水涯線が存在する場合は，その外側にバッファリングす ることで設定し，流水面は便宜上 RMZ に含めた。これは， 地図の誤差（各地図の精度や流路の移動等）によって，流 水面上に林分や植生が含まれてしまう場合にデー夕が欠落 してしまうのを回避するためである（その分結果は微増す る)。RMZ の幅としては，ワシントン州の森林施業規則に おける州西部の核心区域の幅 $15 \mathrm{~m}$ と, 東北 3 県の「基準 と指標」の片岸 $50 \mathrm{~m}$ の二つの值を用い, それぞれ RMZ15, RMZ50 とした。

2）現存植生図を用いた解析

現存植生図から，対象地域や RMZ15，RMZ50，森林区 域と重なる部分をそれぞれ抽出し, 群落別面積を集計し た。群落については，市街地や造成地，落葉果樹園を市街 地等とし, 開放水域, ヌマガヤ, ヨシ, 河辺ヤナギ低木群 落等を水辺植生に, 畑地雑草群落, 牧草地, ササ, シバ等 を草地に, 水田雑草群落は単独で分類し, アカマツやカラ マツ，スギ・ヒノキ・サワラの植栽地や伐採跡地は人工林 に，その他の樹林地は天然林に再集計した。

3）森林資源デー夕を用いた解析

対象地域から，RMZ15, RMZ50，森林区域をそれぞれ抽 出した。集計にあたっては, RMZ を含む林分を水辺林分 と呼び，その林分全体の面積は水辺林分面積, RMZ に含ま れている部分は水辺林分内 $R M Z$ 面積と定義した（図-2）。 そして, 樹種, 林齢, 所有形態, 道路からの距離, RMZ 包 含率, 施業方法の指定, 保安林等の指定に基づいて, 水辺 林分数, 水辺林分面積 (図-2 では緑の部分の面積), 水辺林 分内 $R M Z$ 面積を集計した。

樹種や林齢別面積の集計にあたっては，一つの林分（ポ 


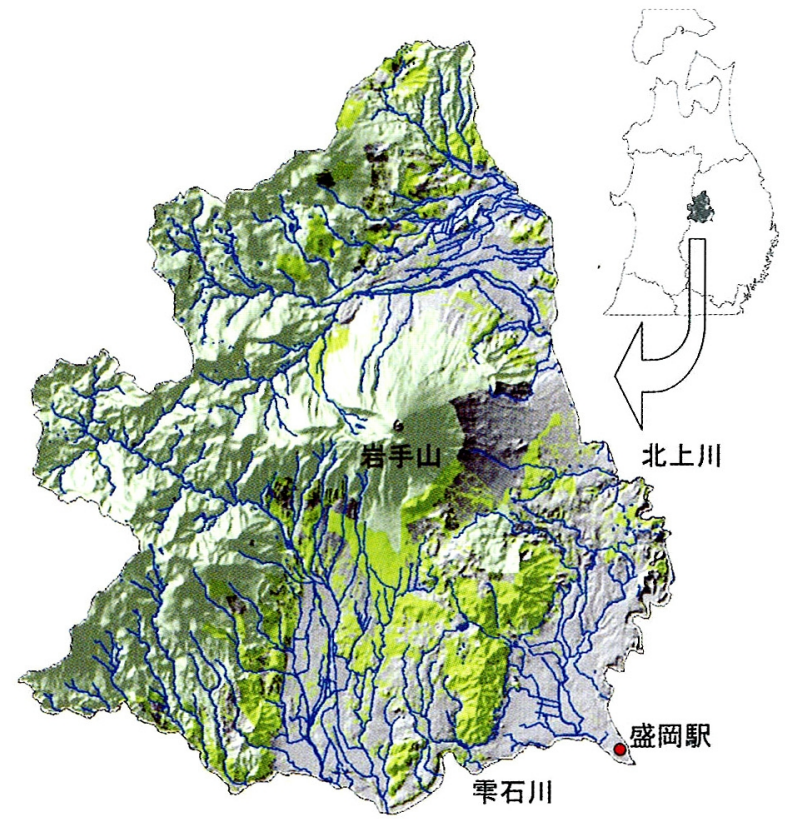

図-1．岩手山周辺地域における水系と森林の分布 国有林，薄緑；民有林，緑；RMZ50，青；先の他，灰色。

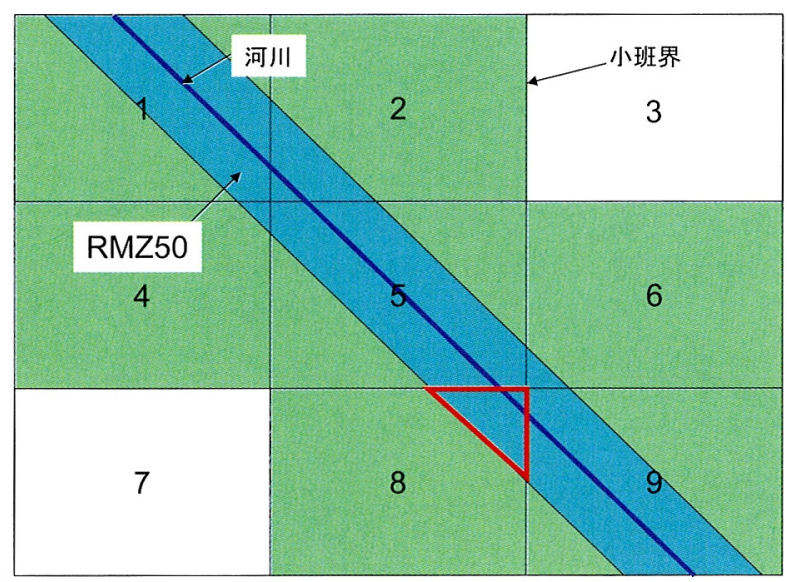

図-2，水辺管理区域と林分との関係についての模式図 注 1 ：九つの林分（ポリゴン）のう占，緑色，水辺林分；白色，他の 林分。注 2:この例では, 1 9 の水辺林分面積は等しいが, 水辺林分 内 RMZ 面積は異なり，林分 8 亿ついては赤い太線で囲われた部分 となる。

リゴン）に対応するレコードが複数存在する場合には，林 分面積を各レコードの面積歩合をもとに比例配分した（一 つの林分に対応する複数レコードの面積歩合の合計は 100 となっている)。

道路から林分までの距離は, 道路区間のラインデータに 対して，50 $\mathrm{m}$ 間隔で $50 \mathrm{~m}$ 未満〜 $1,000 \mathrm{~m}$ 未満までの 20 のバッファーを作成し，それぞれの林分に含まれている道 路バッファーのうち，最も距離の小さいものとした。ま た，RMZ 包含率は，RMZ がある林分のどれだけを占有し ている汃の割合（二水辺林分内 RMZ 面積/水辺林分面積） を計算したものであり，水辺林分を対象として算出した。

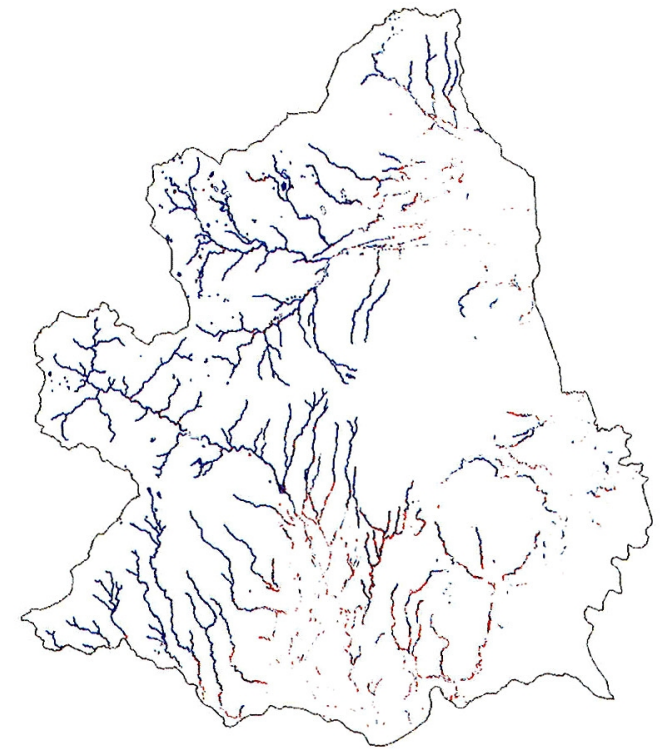

図-3．RMZ15（青）と控除部分（赤）の分布の様子

表-1．岩手山周辺地域の面積の構成

\begin{tabular}{|c|c|c|c|c|c|c|}
\hline 面積（ha） & $\begin{array}{l}\text { 地域 } \\
\text { 全体 }\end{array}$ & $\begin{array}{l}\text { 割合 } \\
(\%)\end{array}$ & RMZ15 & $\begin{array}{l}\text { 割合 } \\
\text { (\%) }\end{array}$ & RMZ50 & $\begin{array}{l}\text { 割合 } \\
(\%)\end{array}$ \\
\hline 地域全体 & 80794 & 100 & 2868 & 4 & 8763 & 11 \\
\hline 森林区域（計画対象） & 53094 & 66 & 1524 & 2 & 4810 & 6 \\
\hline うち国有林 & 38011 & 47 & 968 & 1 & 3070 & 4 \\
\hline うち民有林 & 15082 & 19 & 555 & 1 & 1740 & 2 \\
\hline その他 & 27700 & 34 & 1345 & 2 & 3953 & 5 \\
\hline
\end{tabular}

RMZ を禁伐と想定した場合の補償額の推計にあたって は，「山林素地及び山元立木価格調（日本不動産研究所, 2003）」を参考にして，立木価格を針葉樹人工林 4,000 円/ $\mathrm{m}^{3}$ ，天然林 3,000 円 $/ \mathrm{m}^{3}$ とし，年利率 $2 \%$ もとで， RMZ に含まれるすべての民有林の立木材積を対象隹計算を行っ た（補償額 $=$ 立木価格 $\times$ 林分材積 $\times$ 年利率 : 幼齢林には立 木価格は発生しないが，今後，伐期に達した材積の増加が 見込めることもあり，便宜上含めた)。

現状の施業規制については，施業方法の指定の有無につ いて分析し，国有林については，アカマツ長伐期，スギ・ カラマツ長伐期，ブナ等択伐，天然更新型複層林誘導等に 分類される「施業群」のデー夕項目を使い，民有林につい ては, 択伐，禁伐，その他(岩石地や崩壊地，未立木地等), 指定なしからなる「伐採方法」のデー夕項目を使った。保 安林等の指定については, 保安林の他に, 公園や鳥獣保護 区等の何らかの法的規制を受けるものや，保護林，レクの 森についても対象とした。

\section{III. 結 果と考察}

\section{1. 岩手山周辺地域における水辺管理区域の分析結果}

研究対象である岩手山周辺地域約 80,794 ha のうち, 森 林区域は 53,094 haであり，森林率は66\%であった（表一 
表-2. 植生図に基づく $\mathrm{RMZ}$ の土地利用の分布割合

(\%)

\begin{tabular}{|c|c|c|c|c|c|c|c|c|c|}
\hline \multirow{2}{*}{ 土地利用 } & \multicolumn{3}{|c|}{ 地域全体 } & \multicolumn{3}{|c|}{ 森林区域 } & \multicolumn{3}{|c|}{ 森林区域以外 } \\
\hline & 合 計 & RMZ15 & RMZ50 & 合 計 & RMZ15 & RMZ50 & 合 計 & RMZ15 & RMZ50 \\
\hline 市街地等 & 3 & 3 & 3 & 1 & 1 & 1 & 8 & 5 & 6 \\
\hline 水辺植生 & 1 & 9 & 5 & 0 & 6 & 3 & 3 & 14 & 7 \\
\hline 草 地 & 20 & 15 & 16 & 12 & 13 & 13 & 36 & 17 & 19 \\
\hline 水田雑草群落 & 13 & 27 & 27 & 2 & 6 & 5 & 34 & 51 & 54 \\
\hline 人工林 & 23 & 19 & 20 & 30 & 29 & 31 & 8 & 7 & 7 \\
\hline 天然林 & 40 & 27 & 29 & 55 & 44 & 46 & 11 & 7 & 7 \\
\hline 合 計 & 100 & 100 & 100 & 100 & 100 & 100 & 100 & 100 & 100 \\
\hline
\end{tabular}

1)。岩手県の平均 $77 \%$ と比べて小さいのは, 田園・牧畜地 が多く含まれているためであり, 県内ではやや開けた地域 であるといえる。森林に占める国有林の割合は $72 \%$ と高 く，国有林卓越地域ということができる。

RMZ15，RMZ50 の面積は 2,868 ha，8,763 ha であり， それぞれ地域全体の，4\%，11\%となっていた。RMZの面 積は，ほぼバッファーの幅に比例した。また，RMZにおけ る森林率は $54 \%$ 前後と地域全体に比べて低くなった。この ことは, 水辺域の保全のためには森林を対象とするだけで は十分ではないことを示している。

現存植生図を用いた土地利用状況に関する解析結果は, 表-2 のと扔りである。地域全体では, 天然林が $40 \%$, 人工 林 $23 \%$, 草地 20\%, 水田とその付近の草地（水田雑草群 落） $13 \%$, 市街地等 $3 \%$, 水辺植生 1\% と計算された。地域 に占める RMZ15 の面積割合が $4 \%$ 弱であることを考える と，水辺植生の割合は低いことがわかる。また，RMZ15 内 部では, 天然林と草地がそれぞれ $27 \%, 15 \%$ へと減少し, 反対に, 水辺植生と水田雑草群落が $9 \%$ と $27 \%$ に増加し, 他はわずかな変化となった。このように水田雑草群落が多 くなったのは，RMZの基礎となっている一条河川に水田 耕作用の農業用水路が多く含まれているためである。 RMZ50 については, RMZ15 とほぼ同じ結果であるが，幅 が広がったために水辺植生の割合が $5 \%$ と相対的に低下し た。

このように, RMZ においてさえも, 水辺植生の割合が 10\%に満たないのは, (ア)この地域においては水辺域の固 有植生はさほど残存していない,（イ）水辺植生は水際から わずかな距離で劇的に変化するために近接植生群落に編入 されやすい等の分類の詳細度・精度の問題，のいずれかが 考えられる。

これについて地域全体を森林区域とそれ以外とに分けて 検討した。森林区域において水辺植生の割合が低いのは, 後で述べるように，(イ）の問題を含む森林資源データの分 類方法による影響が大きいと考える。一方，森林区域以外 を対象に（ア）の問題についてみてみると，現存植生図上

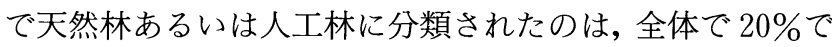
あり, RMZにおいては $14 \%$ と低くなっていた。これらは, 森林計画対象以外の森林や農地に成立した林，公園等の樹 林地であると考えられ，これらと水辺植生を除く $\mathrm{RMZ} の$ $70 \%$ 以上土地が，原植生とはかけ離れた人為の影響を強
く受けたものとなっている。つまり，森林区域以外では （ア）の問題による影響が大きいと考えられる。また, 森林 区域以外では, RMZ における水辺林の割合が少ないこと から，流水温の上昇による魚類等への影響が懸念される。

渓畔林研究会 (2001) は, 河川水温が $20^{\circ} \mathrm{C}$ を越える渓流 でサクラマスの個体数が激減するという研究結果や, 渓畔 林のない区間の総延長が $1 \mathrm{~km}$ に近づくにつれて水温が急 上昇するという研究結果から, 河川の低水温を保持するた めには, 源流部から連続して水辺林を配置することが重要 であることを指摘している。これに関して，本論の研究対 象地域は，先述したイワナやヤマメが多数生息しているだ けでなく，サケの遡上する河川やその上流域となってい る。こうしたサケ科魚類の多くは $10^{\circ} \mathrm{C}$ 付近が適温であり, 約 $20^{\circ} \mathrm{C}$ 以上では生存できないことから, 冷水性の魚と呼 ばれている (水野・御勢, 1972)。このことは, サクラマス と同様の問題が起こりうる可能性があることを意味してお り，森林区域以外の RMZ（水田雑草群落と草地が $70 \%$ を 占めている）においても，水辺林の配置を検討する必要が あると考える。

他方, 森林区域においては, 岩石地・崩壊地以外はほぼ 森林であり，樹冠による日射遮断によって水温上昇の問題 はそれほど深刻ではないと予想される。しかし，水辺林に 求められている水温上昇防止以外の多様な機能について は，水辺固有の植生の割合が低いことが明らかとなり，十 分とはいえない可能性がある。そこで，次節において，そ うした機能と関係すると考えられる樹種や林齢等の偏りに ついて，森林資源デー夕を用いて分析を行った。また，そ うした機能の保全を目的として施業規制を行った場合の森 林所有者に対する影響は, 所有形態ごとの分布や林分面積 等の違いによって異なる可能性が高いことから，こうした 点についても分析した。

\section{2. 森林区域における RMZ の分析結果}

1）樹種および林齢の構成

樹種構成の集計にあたっては, 占有面積の大きなアカマ ツ，カラマツ，スギ，オオシラビソ，ブナ，ミズナラとそ の他針葉樹，その他広葉樹の八つに分類した。これら以外 に特定できた樹種は, ウダイカンバ, カエデ (類), カンバ (類), クリ, クロマツ, コナラ, コメツガ, トドマツ, 八 ンノキ，ヒメコマツ，モミ，ヤチダモの 12 種であったが， これらの面積は $3 \%$ 以下であり, 水辺に出現すると考元ら 
表-3．RMZ における森林の樹種・所有別面積割合

$(\%)$

\begin{tabular}{|c|c|c|c|c|c|c|c|c|c|}
\hline \multirow{2}{*}{ 樹種名 } & \multicolumn{3}{|c|}{ 合 計 } & \multicolumn{3}{|c|}{ 国有林 } & \multicolumn{3}{|c|}{ 民有林 } \\
\hline & 地域全体 & RMZ15 & RMZ50 & 地域全体 & RMZ15 & RMZ50 & 地域全体 & RMZ15 & RMZ50 \\
\hline カラマツ & 14 & 10 & 11 & 13 & 7 & 8 & 18 & 15 & 16 \\
\hline アカマツ & 11 & 7 & 8 & 8 & 5 & 6 & 18 & 9 & 11 \\
\hline ス ギ & 10 & 13 & 13 & 6 & 6 & 7 & 18 & 22 & 22 \\
\hline オオシラビソ & 9 & 7 & 8 & 13 & 12 & 13 & 0 & 0 & 0 \\
\hline 他針葉樹 & 3 & 3 & 3 & 3 & 2 & 3 & 3 & 3 & 3 \\
\hline 針葉樹計 & 48 & 40 & 43 & 43 & 33 & 36 & 58 & 49 & 52 \\
\hline ブ ナ & 19 & 20 & 20 & 29 & 33 & 32 & 0 & 0 & 0 \\
\hline ミズナラ & 4 & 4 & 4 & 5 & 6 & 5 & 0 & 1 & 1 \\
\hline 他広葉樹 & 29 & 36 & 34 & 23 & 28 & 26 & 42 & 49 & 47 \\
\hline 広葉樹計 & 52 & 60 & 57 & 57 & 67 & 64 & 42 & 51 & 48 \\
\hline 合 計 & 100 & 100 & 100 & 100 & 100 & 100 & 100 & 100 & 100 \\
\hline
\end{tabular}

岩石地等の林地以外は除いた割合である。

表-4．RMZにおける森林の所有形態別樹種・齢級構成割合

$(\%)$

\begin{tabular}{|c|c|c|c|c|c|c|c|c|c|c|c|c|c|c|c|c|c|c|c|c|c|c|c|c|c|c|c|}
\hline \multirow[b]{3}{*}{ 樹齢 } & \multicolumn{9}{|c|}{ 森林区域（合計） } & \multicolumn{9}{|c|}{ 国有林 } & \multicolumn{9}{|c|}{ 民有林 } \\
\hline & \multicolumn{3}{|c|}{ 森林区域 } & \multicolumn{3}{|c|}{ RMZ15 } & \multicolumn{3}{|c|}{ RMZ50 } & \multicolumn{3}{|c|}{ 森林区域 } & \multicolumn{3}{|c|}{ RMZ15 } & \multicolumn{3}{|c|}{ RMZ50 } & \multicolumn{3}{|c|}{ 森林区域 } & \multicolumn{3}{|c|}{ RMZ15 } & \multicolumn{3}{|c|}{ RMZ50 } \\
\hline & $\overline{<40}$ & $40 \sim 7$ & $80 \leqq$ & $<40$ & $40 \sim 79$ & $9 \overline{80 \leqq}$ & $<40$ & $40 \sim 79$ & $80 \leqq$ & $\overline{<40}$ & & $80 \leqq$ & $\overline{<40}$ & $40 \sim 79$ & $80 \leqq$ & $<40$ & $40 \sim 79$ & $80 \leqq$ & $<40$ & & $80 \leqq$ & & $40 \sim 79$ & $80 \leqq$ & $<40$ & $40 \sim 7$ & $80 \leqq$ \\
\hline 針葉樹 & 20 & 15 & 12 & 13 & 14 & 11 & 15 & 15 & 12 & 20 & 6 & 16 & 12 & 6 & 15 & 14 & 6 & 16 & 19 & 33 & 4 & 14 & 27 & 6 & 16 & 28 & 6 \\
\hline 広葉樹 & 5 & 13 & 34 & 6 & 18 & 35 & 6 & 17 & 34 & 2 & 5 & 50 & 1 & 8 & 58 & 1 & 7 & 55 & 11 & 30 & 1 & 14 & 34 & 1 & 13 & 32 & 1 \\
\hline 合計 & 25 & 28 & 47 & 19 & 33 & 46 & 21 & 32 & 46 & 22 & 11 & 66 & 13 & 14 & 73 & 15 & 13 & 72 & 30 & 63 & 5 & 28 & 62 & 7 & 29 & 61 & 7 \\
\hline
\end{tabular}

各区分を針葉樹・広葉樹の別と三つの林齢階によって分類した面積割合を示した。例えば，国有林で RMZ15に含まれる六つの項目の合計は $100 \%$ なる。

れるカンバ (類)，ハンノキ，ヤチダモを取り出すとさらに その $1 / 10$ 以下となった。これは，水辺域に固有な樹種を特 定し切れていないことを示しているが，その主な原因とし て，(1)林分の優占種ではないために表記されていない，あ るいは，(2)「その他針葉樹」や「その他広葉樹」に分類され たことが考えられる。つまり，ここで用いた森林資源デー 夕は, 水辺域の植生解析には向いていないということがで きる。

しかしながら，森林資源データを用いて，林種転換等の 影響を把握することは可能である。そこでまず，樹種構成 について集計した（表-3）。地域全体では，針葉樹と広葉樹 の割合は同程度であり，針葉樹では，カラマツ，アカマツ， スギの順に多くなっていた。これに対して, RMZにおいて は，広葉樹の割合が $60 \%$ 前後に増加し，針葉樹では，乾燥 した場所に適するカラマツとアカマツが減って，スギが増 加した。この結果からは，この地域の水辺域では，やや針 葉樹人工林化は控えられていることがわかる。

国有林についてみてみると，高標高地に林分が分布して いることもあり，ブナやオオシラビソ，ミズナラの割合が $50 \%$ 前後を占めた。人工林の割合は，地域全体では $29 \%$ で あるのに対して RMZ においては $20 \%$ 程度と低く，自然度 の高さを伺わせる結果となっている。同様に民有林につい てみてみると，人工林の割合は，地域全体の $47 \%$ と比べて RMZ においては $42 \%$ へ低下した。

次に，林齢構成を表 -4 に示した。森林区域では，80 年生 以上の林分が面積割合で $50 \%$ 弱あり，その多くは広葉樹林 であった。また，40 年生末満の若い林は $25 \%$ あ,このほ とんどは針葉樹人工林であった。一方， RMZ においては， 40 年生未満の林分が減少した。なお，民有林では 80 年生
以上の水辺林分は 7\%しかないことが明らかとなった。

水辺林には水流を覆うのに十分な樹高が必要であること や，人為的攪乱の影響を抑える，あるいは，寿命の長い水 辺固有種の種子生産を確保するためには林齢はある程度高 いことが望ましいと考えられる。さらに，倒流木等によっ て形成される自然のダムは魚類等の重要な生息域となるの で，それを形成するような大径倒木が供給されるためには 高齢林分の存在が重要である（Richards and Hollingsworth，2000）。こうした観点からすると，特に民有林部分 に颃いて，林齢が十分高いとはいえない状況であるといえ る。

なお，樹種と林齢の解析においては，RMZ の幅による 結果の違いはあまりみられなかった。これは，国有林と民 有林の水辺林分数が, RMZ15 においてはそれぞれ, 1,250, 3,921 であるのに対して, RMZ50 では 1,623，6,027 と面 積の割には増加しなかったためである。

2） $\mathrm{RMZ}$ の導入が水辺林分の林業経営へ及ぼす影響

RMZ15に含まれる 4\%の民有林は, 地域全体からする とさほど大きくないと感じられるが，水辺林分を所有する 個別の森林所有者への影響は違ったものになると想像され る。そこで，そうした影響について詳しくみていくことに する。

所有形態別の面積構成を表 -5 に示した。森林区域に占 める割合は，国有林 $72 \%$, 個人有林 $12 \%$, 会社有林 $7 \%$ に 対して, RMZ 内森林面積に占める国有林の割合は $64 \%$ に 低下し，対照的に，個人有林と会社有林の割合がそれぞれ 17，10\%へと増加した。これは，河川の少ない高標高（上 流）部に国有林が分布しているのに対して，民有林は河川 の多く存在する中〜低標高部に分布しているためであると 
表-5. RMZ における所有形態別森林面積およびその割合

\begin{tabular}{lrrrrrrr}
\hline & \multicolumn{3}{c}{ 面積 (ha) } & & \multicolumn{3}{c}{ 割合 (\%) } \\
\cline { 2 - 3 } \cline { 6 - 8 } & 地域全体 & RMZ15 & RMZ50 & & 地域全体 & RMZ15 & RMZ50 \\
\hline 国有林 & 38011 & 968 & 3070 & & 72 & 64 & 64 \\
個 人 & 6588 & 257 & 791 & & 12 & 17 & 16 \\
会 社 & 3760 & 153 & 492 & & 7 & 10 & 10 \\
公社, 公団等 & 1298 & 53 & 153 & & 2 & 3 & 3 \\
市町村 & 1844 & 30 & 105 & & 3 & 2 & 2 \\
共有林 & 681 & 33 & 95 & & 1 & 2 & 2 \\
県有林 & 846 & 26 & 91 & & 2 & 2 & 2 \\
社寺他 & 32 & 1 & 4 & & 0 & 0 & 0 \\
合 計 & 53061 & 1521 & 4802 & & 100 & 100 & 100 \\
\hline
\end{tabular}

表-1の合計とあわないのは，民有林データにおいてポリゴンがあるのに 資源デー夕のないものが RMZ15，RMZ50 についてそれぞれ, 3 ha, 8 ha 存在するためである。

考えられる。

次に，水辺林分に抢ける林業への影響をみるために，経 済性の重要な要素となる道路からの距離と，何らかの施業 規制を受けた場合に林分のどれだけの割合が対象となるか を表す RMZ 包含率に基づいて，その林分数を集計した (表-6)。その結果, 道路からの距離が $200 \mathrm{~m}$ 未満の木材生 産に適した林分数は，地域全体では，国有林で $72 \%$ ，民有 林で 85\%であるのに対して，RMZ15 と関連する水辺林分 では，それぞれ $80 \% ， 90 \%$ に上昇した。このことから，こ の地域の水辺林分は相対的に出材しやすい場所に多いとい える。また, RMZ の幅が 3 倍以上に増加しても，民有林の 水辺林分数は, 3,921 から 6,027 までの増加にとどまって いるのに対して，RMZ 包含率 40\%以上となっている林分 の割合は，RMZ15 の場合，国有林の $20 \%$ に対して，民有 林では $32 \%$ と高い割合となっており, RMZ50 では，それぞ れ 43\%，63\%に上昇した。このことは, RMZ の幅を増加さ せた場合, RMZ 包含率の増加に大きく影響することを示 している。加えて, 道路から近い林分で RMZ 包含率が高 い傾向がみられ，それは特に民有林において顕著であった。 なお，伐採規制の影響の大きい人工林の割合を，RMZ 包 含率が $40 \%$ 以上でかつ $200 \mathrm{~m}$ 未満の林分を対象にみると, RMZ15 の場合，民有林では 46\%に達しているのに対して 国有林では $12 \%$ と低く，RMZ50ではそれぞれ $51 ， 26 \% に$ 上昇した。

以上のことから，水辺林に対する施業規制を，控除措置 を取らずに実施した場合，その影響は民有林に顕著に表 れ，RMZ の幅が大きいほど影響も大きくなるということ
ができる。たとえば，伐採する場合に，林分面積の $40 \%$ 以 上が施業規制を受けると，機械費等の費用が変わらないの に伐採材積が大きく減少するため, 単位材積あたりの伐採 コストが大きく上昇すると考えられる。また, RMZ の幅が $50 \mathrm{~m}$ の場合には，民有林の 3,499 林分がそうした対象とな り，水辺林分面積の合計は 1,734 ha に達する。そして，そ の大部分が個人または会社有林であることから，合意形成 の難航が懸念される。

森林所有者の施業規制に対する合意を促す一つの手段と して, 保安林において講じられている補償措置が参考にな る。藤沢（1960）によれば，森林法第 35 条の「通常受ける べき損失を補償しなければならない」という規定は，権利 侵害の程度が社会的受認の限度を超えたものであることが 前提であり，それは，適正伐期齢以上における伐採方法の 制限，すなわち禁伐と単木択伐の指定に適用される。ここ では, RMZ が禁伐となった場合について試算を行った。そ の結果, RMZ15 については, 12 万 $\mathrm{m}^{3}$ を対象とする総額 842 万円の補償が毎年発生し, RMZ50 では, 37 万 $\mathrm{m}^{3}$ を対 象とする 2,644万円と推計された。ただし, これは RMZ 部 分のみを対象とした試算であり, 保安林のように林分全体 を指定する場合には，この額のさらに $2 \sim 3$ 倍が必要とな る。

一方，すでに何らかの施業規制がなされていれば，新た な規制の影響は緩和される可能性がある。そこで, RMZ15 を伐採方法と保安林等の指定に基づいて分類した（表-7）。 結果をみると，保安林等の指定を受けている面積の割合 は，国有林では $87 \%$ と非常に高いものの，民有林では $21 \%$ にとどまっていた。加えて，そうした指定のもとで伐採方 法が択伐や禁伐に指定されている面積の割合は, 国有林で $1 \%$ ，民有林で $6 \%$ にすぎないことがわかった。つまり，保 安林や自然公園等の指定を通じた水辺林に対する施業規制 の現状としては，伐採方法にまで踏み込んでいる割合はわ ずかであることがわかる。さらに，保安林や自然公園等を 所管する法規において，水辺域に関する具体的な記述がな いことから，現状の水辺林に対する施業規制は緩く，新た な規制導入の影響はそのまま表れるといえる。

その影響は, 民有林に表れる可能性が高いと考えられる。 なぜなら, 国有林では,「人との共生林」については天然林 を保全し，人工林を天然林に誘導する，「水土保全林」と 「循環利用林」では, 渓流沿い等に保護樹帯をおううむね幅

表-6. 道路からの距離と $\mathrm{RMZ}$ 包含率による水辺林の林分数の割合

$(\%)$

\begin{tabular}{|c|c|c|c|c|c|c|c|c|c|c|c|c|c|c|c|c|}
\hline & \multirow{2}{*}{$\begin{array}{c}\text { 道路からの } \\
\text { 最短距離 }\end{array}$} & \multirow{2}{*}{$\begin{array}{l}\text { 森林 } \\
\text { 区域 }\end{array}$} & \multicolumn{7}{|c|}{ RMZ15 } & \multicolumn{7}{|c|}{ RMZ50 } \\
\hline & & & 合計 & 20 末満 & $20-$ & $40-$ & $60-$ & $80-$ & 100 & 合計 & 20 未満 & $20-$ & $40-$ & $60-$ & $80-$ & 100 \\
\hline \multirow{4}{*}{$\begin{array}{l}\text { 峟 } \\
\text { 林 }\end{array}$} & $100 \mathrm{~m}$ 未満 & 66 & 72 & 34 & 15 & 10 & 6 & 6 & 1 & 71 & 17 & 10 & 8 & 8 & 20 & 9 \\
\hline & $200 \mathrm{~m}$ 未満 & 19 & 18 & 8 & 4 & 3 & 2 & 1 & 0 & 19 & 4 & 3 & 2 & 2 & 5 & 3 \\
\hline & $200 \mathrm{~m}$ 以上 & 15 & 9 & 4 & 2 & 1 & 1 & 1 & 0 & 10 & 3 & 2 & 1 & 1 & 3 & 1 \\
\hline & 合 計 & 100 & 100 & 46 & 22 & 14 & 9 & 8 & 1 & 100 & 24 & 14 & 11 & 11 & 28 & 13 \\
\hline \multirow{4}{*}{$\begin{array}{l}\text { 国 } \\
\text { 有 } \\
\text { 林 }\end{array}$} & $100 \mathrm{~m}$ 末満 & 61 & 71 & 49 & 8 & 6 & 4 & 4 & 1 & 71 & 30 & 10 & 6 & 5 & 13 & 6 \\
\hline & $200 \mathrm{~m}$ 末満 & 11 & 9 & 5 & 2 & 1 & 0 & 1 & 0 & 9 & 3 & 1 & 1 & 1 & 2 & 1 \\
\hline & $200 \mathrm{~m}$ 以上 & 28 & 20 & 14 & 3 & 2 & 1 & 1 & 0 & 20 & 9 & 3 & 2 & 2 & 3 & 1 \\
\hline & 合 計 & 100 & 100 & 67 & 13 & 9 & 5 & 5 & 1 & 100 & 43 & 14 & 9 & 8 & 18 & 8 \\
\hline
\end{tabular}




\begin{tabular}{|c|c|c|c|c|c|c|c|c|}
\hline \multirow{2}{*}{ 伐採方法の指定 } & \multicolumn{4}{|c|}{$\begin{array}{l}\text { 面 積 (ha) } \\
\end{array}$} & \multicolumn{4}{|c|}{ 割 合 (\%) } \\
\hline & 合計 & 規制なし & 保安林 - 砂防指定 & 公園・緑地等 & 合計 & 規制なし & 保安林・砂防指定 & 公園・緑地等 \\
\hline \multicolumn{9}{|l|}{ 民有林 } \\
\hline な し & 504 & 417 & 73 & 14 & 91 & 75 & 13 & 2 \\
\hline その他 & 16 & 15 & 0 & 0 & 3 & 3 & 0 & 0 \\
\hline 禁伐・択伐 & 34 & 0 & 33 & 1 & 6 & 0 & 6 & 0 \\
\hline 合 計 & 553 & 433 & 105 & 15 & 100 & 78 & 19 & 3 \\
\hline \multicolumn{9}{|l|}{ 国有林 } \\
\hline な し & 712 & 51 & 633 & 27 & 90 & 6 & 80 & 3 \\
\hline その他 & 61 & 34 & 27 & 0 & 8 & 4 & 3 & 0 \\
\hline 禁伐・択伐 & 16 & 8 & 7 & 0 & 2 & 1 & 1 & 0 \\
\hline 合＼cjkstart計 & 788 & 93 & 668 & 27 & 100 & 12 & 85 & 3 \\
\hline
\end{tabular}

国有林については，施業群を用いたため，樹林地のみの集計となり，合計值は 788 haである。

表-8. 所有形態別にみた森林区域内の RMZ15 の控除対象面積とその割合

\begin{tabular}{|c|c|c|c|c|c|c|c|c|c|c|}
\hline \multirow{2}{*}{ 所有形態 \控除対象 } & \multicolumn{3}{|c|}{ 林分面積別の控除面積（ha） } & \multirow{2}{*}{$\begin{array}{c}8 \text { ha 以上 } \\
\text { の面積 }\end{array}$} & \multirow{2}{*}{$\begin{array}{l}\text { RMZ の } \\
\text { 面積合計 }\end{array}$} & \multicolumn{3}{|c|}{ 林分面積別の控除割合（\%) } & \multirow{2}{*}{$\begin{array}{l}8 \mathrm{ha} \text { 以上 } \\
\text { の面積割合 }\end{array}$} & \multirow{2}{*}{ 合計 } \\
\hline & 1 ha 未満 & 1 2 ha 未満 & 2 8 ha 未満 & & & 1 ha 未満 & 1 2 ha 未満 & 2 8 ha 未満 & & \\
\hline 国有林 & 49 & 150 & 116 & 653 & 968 & 5 & 16 & 12 & 67 & 100 \\
\hline 県・市町村有林 & 11 & 10 & 21 & 15 & 56 & 19 & 17 & 37 & 27 & 100 \\
\hline 公社, 公団 & 10 & 6 & 26 & 10 & 53 & 20 & 12 & 48 & 20 & 100 \\
\hline 会社 & 59 & 26 & 52 & 16 & 153 & 39 & 17 & 34 & 10 & 100 \\
\hline 共有林 & 12 & 9 & 5 & 7 & 33 & 36 & 29 & 15 & 20 & 100 \\
\hline 個人 & 174 & 38 & 35 & 9 & 257 & 68 & 15 & 14 & 4 & 100 \\
\hline その他 & 1 & 0 & 0 & 0 & 1 & 56 & 0 & 44 & 0 & 100 \\
\hline 民合計 & 267 & 90 & 139 & 57 & 553 & 48 & 16 & 25 & 10 & 100 \\
\hline 全合計 & 316 & 240 & 255 & 711 & 1,521 & 21 & 16 & 17 & 47 & 100 \\
\hline
\end{tabular}

$50 \mathrm{~m}$ 以上で設けるという水辺林に対する管理指針（東北 森林管理局青森分局，2001）を策定し，それを実施してい るからである。

ところで，ワシントン州では，面積の小さい林分や小規 模森林所有者に対しては，施業規制を控除するという措置 がとられている。そこで，同様の措置をとった場合の影響 について分析した。残念ながら，森林所有者ごとの所有規 模は不明であることから，ここでは，一部が RMZ15 に含 まれている林分の面積規模に基づいて，控除対象となる RMZ 内森林面積を集計した (表-8)。その結果, ワシント ン州と同様に 8 ha 未満を控除対象とした場合，国有林で は 33\%，民有林に至っては 89\%の RMZ 対象地が控除さ れた。これに対して，控除の基準を 2 ha 未満に下げた場合 には, 国有林 $21 \%$, 民有林 $64 \%$ へと控除率が減少した。し かし，民有林ではなおも約 $2 / 3$ が控除対象となった。この 地域では，国有林と民有林の分布域に偏りがあることか ら，このような高い控除率の下では，図-3 のように，標高 の低い地区においては，保全されるべき RMZ が分断ある いは断片化され，水辺域の生態系の連続性や相互連関が阻 害される結果となった。さらに，控除の基準を 1 ha 未満に 下げても，民有林では依然として $48 \%$ と高く，その半分近 くを占める個人有林では, 面積の小さい林分が多いことも あって，控除率は $68 \%$ となった。

以上の結果をまとめると，RMZ 導入することによっ て，水辺林分に対して施業規制を行った場合には，RMZ には民有林が多く，出材しやすい場所が多い上に，現状の
施業規制が緩いことから木材生産に与える影響は大きいと いえる。特に，RMZ の幅を大きく（たとえば $50 \mathrm{~m} ）$ とつ て禁伐とする場合には, RMZ 包含率が大きくなり，木材生 産に大きな支障が出る。これに対して，補償を行う場合に は，その額は高額となる。他方，林分面積の小さいものを RMZ の対象から控除するという手段も考えられるが，木 材生産への影響は大きく緩和されるものの, RMZ の多様 な機能の発揮を阻害する可能性が高い。これらのことから， 包括的かつ実効性のある水辺林の保全のためには，林分規 模の小さい個人有林等については, RMZ の幅を小さくし, 施業要件を緩和する等の措置が適当であると考える。

\section{IV.おわりに}

本研究においては，水辺管理区域の幅を $15 \mathrm{~m}$ ，あるいは $50 \mathrm{~m}$ として解析を行った。適正な幅については, 生態学的 な立場によって大きく異なるようであるが，保全幅は大き いほど多様な効果を発揮しやすいと思われる。しかし，日 本の水辺域には様々な土地利用や土地所有が存在してお り，本結果からも幅が大きいほど土地所有者への影響は大 きくなると考えられる。また，本論では水辺管理区域の幅 は一律のものとして解析を行ったが, 現実的には場所に応 じて必要な幅は変わってこよう。保全すべき水辺域やその 幅等を具体的に検討するにあたっては，現地調査を行っ て, 現存している水辺植生や潜在的に復元可能な候補地等 に関するデー夕を収集することが，今後の課題と考える。

保全すべき対象が選定されたとして，そうした土地をど 
の様に管理すれば，水辺林の生態学的機能を発揮させるこ とができるのかを検討することも今後の課題となろう。原 植生に近づけていくことが望ましいものと思われるが，た とえば現状が人工林であった場合，皆伐した後に人工植栽 を行わずに回復させるのがよいのか，あるいは択伐によっ て混交林化していくのか（伐採率や選木方法，回帰年はど うするか)，それとも禁伐にすることで回復を待つのがよ いのか等々, さらなる研究が求められるところである。そ うした管理方法が明らかとなれば，水辺林の保全に適用で きると同時に，何らかの施業規制を行う場合，水辺管理区 域に含まれた森林所有者に対して適切な補償措置を講じる ことができる。

なお本論では，行政による施業規制を念頭に議論を進め たが，水辺域の保全のあり方としては，森林所有者自らの 自発的な取り組みも重要である。これに関連して，森林認 証取得の取り組みをあげることができる。その認証取得の 条件として，「緩衝帯の幅は，小規模の渓流の場合両岸 5 $\mathrm{m}$ ，中規模の渓流の場合両岸 $10 \mathrm{~m} 」 と し ， 「$ 広葉樹林の導 入を図る」とするものが存在する（岩泉町, 2003)。最近, グリーン（環境に配慮した製品の選択的な）購入が拡大し ていることから，このような木材を供給する側の環境保全 への取り組みの必要性は増しているといえる。

最後に，岩手山周辺地域では，森林区域だけを取り出す と, 当初予想していたよりも水辺環境が良好であるという 結果が得られた。それは, 旧薪炭林がそのまま残されてき たことと，国有林が多く各種保護地域を抱えていることに よるのではなかろうか。もしそうであるとすれば，同様の 解析を人工林や民有林の卓越地域で行うと, 全く違った結 果が得られることが予想される。そうした比較研究が今後 の課題となろう。

\section{引用文献}

藤森隆郎・由井正敏・石井信夫（1999）森林における野生生物の保護 管理. $255 \mathrm{pp}$, 日本林業調査会, 東京. 藤沢秀夫（1960）保安林の損失補償. 水利科学 4:123-134.
岩泉町 (2003) 岩泉町森林認証グループマニュアル (渓畔林関係). 50 pp, 岩泉町.

岩手県農林水産部（2002）岩手県の木材需給と木材工業の現況. 82 $\mathrm{pp}$, 岩手県.

柿澤宏昭（2000） 8. 水辺林管理域設定に関する社会的・制度的問題. (水辺域管理). 砂防学会編, $329 \mathrm{pp}$, 古今書院, 東京.

環境省 (2004) 希少猛禽類調査（イヌワシ・クマタカ）の結果につい て. 環境省, http://www.env.go.jp/press/press.php3?serial $=5218$.

渓畔林研究会 (1997) 水辺林の保全と再生に向けて. $218 \mathrm{pp}$, 日本林 業調査会, 東京.

渓畔林研究会 (2001) 水辺林管理の手引き. 213 pp, 日本林業調查会, 東京.

国土地理院 (2003) 平成 14 年 2 万 5 千分 1 地形図図式. $114 \mathrm{pp}$, 日本 測量協会, 東京.

久保山裕史 (2001) 第 1 章 1990 年以降の米国の森林・林業, 林産物 貿易の動向とその土地利用・環境に与えた影響.（世界貿易機関 次期交渉緊急対応事業, 農林水産物貿易の発展が畜産的・林業的 土地利用の変化と環境に与える影響に関する調査平成 12 年度事 業報告書. $260 \mathrm{pp}$ ，(財)林業科学技術振興所, 東京.

緑のグランドデザイン検討委員会・基準と指標を検討する専門部会 （2001）北東北における持続可能な森林経営に向けた基準と指標 の解説. $16 \mathrm{pp}$, 青森県. (http://apple.net.pref.aomori.jp/rinshi/北 東北基準と指標解説. pdf).

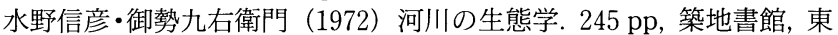
京.

日本不動産研究所（2003）山林素地及び山元立木価格調. 39 pp, 日 本不動産研究所, 東京.

岡村俊邦 - 孫田 敏 (2000) 7. 水辺林の再生. (水辺域管理. 砂防学会 編, $329 \mathrm{pp}$, 古今書院, 東京).

Richards, C. and Hollingsworth, B. (2000) Managing riparian areas for fish. In Riparian management in forests, Edited by Verry, E.S., Hornbeck, J.W., and Dolloff, C.A. (eds.), 402 pp, LEWIS Publishers, New York.

高橋和也・林 靖子・中村太士・辻 珠希・土屋 進・今泉浩史 (2003) 生態学的機能維持のための水辺緩衝林帯の幅に関する考察. 応 用生態工学 5:139-167.

東北の渓流釣り場ガイド編集部（1998）岩手県の渓流盛岡起点日㷌 り 1 泊で楽しめる県北編. $151 \mathrm{pp}$, 山と渓谷社, 東京.

東北森林管理局青森分局 (2001) 森林施業の手引き. $105 \mathrm{pp}$, 東北森 林管理局青森分局, 青森.

Washington Forest Practice Board (2001) Administrative Code of Washington, Chapter 222-30. 39 pp, (http://www.leg.wa.gov/ $\mathrm{wac} /$ index.cfm? fuseaction $=$ title\&title $=222$ )

鷲谷いづみ・草刈秀紀編 (2003) 自然再生事業. 371 pp, 築地書館, 東 京. 